Systematic Review

\title{
Full-Endoscopic Procedures Versus Traditional Discectomy Surgery for Discectomy: A Systematic Review and Meta-analysis of Current Global Clinical Trials
}

Xiao-Chuan Li, MD, Cheng-Fan Zhong, MD, Gui-Bin Deng, MD, Rong-Wei Liang, MD, and Chun-Ming Huang, MD

From: Department of Orthopedics Surgery, Gaozhou People's Hospital, No 89, XiGuan Road, Guangdong 525200,

China

Address Correspondence: Chun-Ming Huang, MD Department of Orthopedics Surgery

Gaozhou People's Hospital No 89, Xi-Guan Road, Guangdong 525200, China E-mail:

1553285402@qq.com

Disclaimer: There was no external funding in the preparation of this manuscript. Conflict of interest: Each author certifies that he or she, or a member of his or her immediate

family, has no commercial association (i.e., consultancies, stock ownership, equity interest, patent/licensing arrangements, etc.) that might pose a conflict of

interest in connection with the submitted manuscript.

Manuscript received: 03-21-2015 Revised manuscript received: 07-25-2015, 09-24-2015 Accepted for publication: 09-29-2015

Free full manuscript: www.painphysicianjournal.com
Background: Traditional discectomy surgery (TDS) provides good or excellent results in clinical surgical discectomy but may induce neural adhesion, spinal structural damage, instability, and other complications. The potential advantages of full-endoscopic (FE) procedures over standard TDS include less blood loss, less postoperative pain, shorter hospitalization, and an earlier return to work. However, more evidence is needed to support this new technology in clinical applications.

Objective: The aim of this systematic review and meta-analysis was to compare the safety and efficacy of FE and TDS.

Study Design: Comprehensive systematic review and meta-analysis of the literature.

Methods: Electronic databases, including PubMed, EMBASE, SinoMed, and Cochrane Library, were searched to identify clinical therapeutic trials comparing FE to TDS for discectomy.

Results: Six trials comprising 730 patients were included, and the overall quality of the literature was moderate, including 4 Grade I levels of evidence (4 randomized controlled trials, [RCTs]) and 2 Grade II levels (2 non-RCTs). The pooled data revealed no difference in reoperation rates between FE and TDS ( $P=0.94)$, but the complication rate was significantly lower in the FE group $(3.86 \%)$ than in the TDS group (11.4\%). Perioperative parameters (operation time, blood loss, hospitalization time, and return to work days) were significantly lower in the FE group $(P<0.05$ for all groups using either score). Postoperative pain and neurology score assessments were conducted at 4 different time points at 3 months, 6 months, 12 months, and 24 months. Significant differences were detected in the following: lumbar North American Spine Society (NASS) pain at 6 months ( $P$ $=0.008)$; cervical NASS neurology at 6 months $(P=0.03)$; visual analog scale (VAS) score in leg at 3 months $(P<0.001)$; VAS score in arm at 24 months $(P=0.002)$; VAS score in neck at 3 months, 6 months, and 12 months after therapy $(P=0.003, P=0.004, P=0.01)$; and VAS score in neck at 3 months and 6 months $(P=0.01, P=0.004)$. Moreover, the pooled data revealed no statistically significant differences in improvements in the Oswestry disability index (ODI), instability (X-ray), and Hilibrand criteria ( $P>0.05$ for all groups).

Limitations: Only 6 studies were included, 4 of which had the same authors. Between-study heterogeneity due to differences in socioeconomic factors, nutrition, and matching criteria is difficult to avoid.

Conclusions: Based on this meta-analysis of 24 months of clinical results, we conclude that the FE procedure is as effective as TDS but has the additional benefits of lower complication rates and superior perioperative parameters. In addition, patients may experience less pain with FE techniques due to a smaller incision and less operative injury. However, large-volume, well-designed RCTs with extensive follow-up are needed to confirm and update the findings of this analysis.

Key words: Full-endoscopic, minimally invasive, discectomy, meta-analysis

Pain Physician 2016; 19:103-118 
$\mathbf{N}$ eck and back pain are the most common disorders in orthopedic clinics and are mainly due to disc degeneration. These disorders not only lead to heavy social and familial financial burdens but also impact the mental health of patients (1-4). According to recent research statistics (2), in the United States, economic losses caused by neck pain exceed 100 billion US dollars annually. Conventional open surgical techniques provide good or excellent results in patients whose symptoms fail to improve with conservative management $(5,6)$, but these techniques may induce neural adhesion, spinal structural damage, instability, and other complications (7-11).

Minimally invasive surgery, though different from conventional open surgery, should be nearly or exactly as effective as conventional open techniques (12). Several recent systematic reviews have compared minimally invasive discectomy, but these studies were limited to tubular or microendoscopic surgery or other surgical procedures $(9,12-19)$. Full-endoscopic (FE) discectomy $(20,21)$ is a new type of minimally invasive spinal surgery designed to reduce surgical trauma, accelerate postoperative recovery, and maintain the integrity of the normal anatomy of the spine. However, it may be associated with increased risks of neurological injury, incidental durotomy, and reoperation (22-24). In addition, a learning curve is required before surgeons can use this technique effectively and reliably (25-27). Therefore, the use of this technique should be guided by high-quality evidence (28). However, there is still no quantitative evidence about whether FE achieves better or worse outcomes than traditional discectomy surgery (TDS).

Thus, a meta-analysis is needed to examine the improvement in clinical outcomes, perioperative parameters, and complications for FE discectomy versus TDS. The aim of this study was to compare the efficacy and safety of FE discectomy and TDS.

\section{Methods}

We followed the protocol outlined in the Cochrane Handbook for Systematic Reviews of Interventions (29). The study was designed and reported according to the Preferred Reporting Items for Systematic Reviews and Meta-Analyses (PRISMA) Statement $(30,31)$.

\section{Search Strategy}

The PubMed, EMBASE, MEDLINE, SinoMed, and Cochrane Library databases were searched on January 31, 2015, without restriction to regions, publication types, or language. Information retrieval was specific to human studies. The search strategy is shown in Fig. 1 , and the related articles function was also used to broaden the search. The computer search was supplemented with manual searches of the reference lists of all retrieved studies and review articles.

\section{Eligibility Criteria}

Two reviewers independently extracted relevant information from each eligible study. Information about the characteristics of the study participants, details of the interventions used, and comparisons as well as relevant outcomes were recorded. Clinical studies in the form of randomized controlled trials (RCTs) or nonrandomized controlled trials (non-RCTs) in any phase were included. The exclusion criteria were as follows: comparative single-arm or no sham trials, case series, case reports, review articles, editorials, letters, surveys, economic studies, articles on laparoscopic spinal fusion, and unrelated publications. Finally, the outcomes were cross-checked independently, and any inconsistencies in results were discussed. The exhaustive searches are detailed in Table 1.

\section{Methodological Evaluation and Data Analysis}

The quality of each included study was evaluated by the Cochrane Handbook for Systematic Reviews of Interventions (version 5.1.0). RCTs were evaluated using the Cochrane Collaboration tool for assessing the risk of bias (29), and non-RCTs were assessed using the modified Newcastle-Ottawa scale $(32,33)$, which consists of 3 factors: patient selection, comparability of the study groups, and assessment of outcome. A score of 0 - 9 (allocated as stars) was allocated to each study. Studies achieving 6 or more stars were considered high quality. All meta-analyses were performed using Review Manager 5.2.0 (Cochrane Collaboration, UK). The weighted mean difference (WMD) and risk ratio (RR) were used to compare continuous and dichotomous variables, respectively. All results are reported with $95 \%$ confidence intervals (Cls). Statistical heterogeneity between studies was assessed using the chi-square test. Values of $12>$ $50 \%$ or $P<0.10$ indicated heterogeneity between different trials. When the standard deviation (SD) could not be obtained, to obtain more credible results, we evaluated the SD as half the mean (M) in 4 trials (34-37).

\section{Quality Assessment}

The quality of the evidence was assessed according to the guidelines of the Grading of Recommendations, 


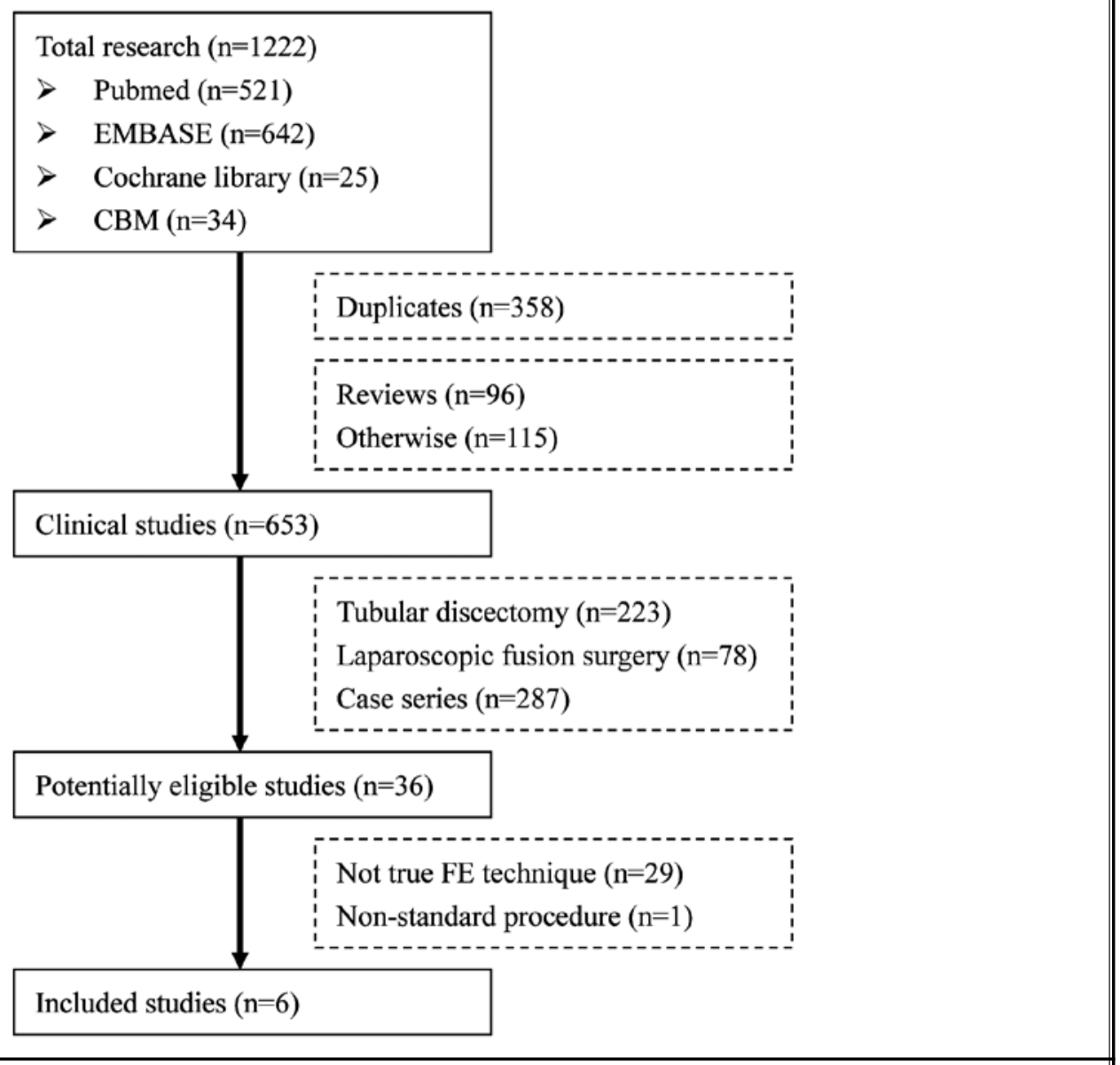

Fig. 1. Flow diagram sketches the current systematic review and meta-analysis identified, screened, included and excluded.

Assessment, Development, and Evaluation (GRADE) working group (38-40). The evidence grades are divided into the following categories: (1) high, which indicates that further research is very unlikely to change confidence in the effect estimate; (2) moderate, which indicates that further research is likely to significantly alter confidence in the effect estimate and may change the estimate; (3) low, which indicates that further research is very likely to significantly change confidence in the effect estimate and to change the estimate; and (4) very low, which indicates that any effect estimate is uncertain.

\section{Data Synthesis}

A meta-analysis and comparison were conducted if 2 or more included studies involved clinical and statistical homogeneous results. When not possible due to the small number of studies or heterogeneity, a qualitative descriptive analysis was performed.

\section{Results}

The PubMed, EMBASE, SinoMed, and Cochrane Library databases were searched (Fig. 1). Six studies including 730 cases fulfilled the predefined inclusion criteria $(34-37,41,42)$. Examination of the references cited in these studies and review articles did not yield any further studies for evaluation.

\section{Characteristics of Eligible Studies}

The detailed information of the 6 trials (4 RCTs and 2 non-RCTs) included in the meta-analysis are summarized in Table 1 . There were 2 trials $(35,37)$ of cervical discectomy and 4 studies of lumbar discectomy $(34,36,41,42)$. In the FE treatment group, 3 trials used a 
Table 1. Characteristics of the 6 included studies.

\begin{tabular}{|c|c|c|c|c|c|c|c|c|c|c|c|c|}
\hline Characteristic & \multicolumn{2}{|c|}{$\begin{array}{c}\text { Lee } 2009 \\
(41)\end{array}$} & \multicolumn{2}{|c|}{$\begin{array}{c}\text { Ruetten } 2008 \\
(37)\end{array}$} & \multicolumn{2}{|c|}{$\begin{array}{c}\text { Ruetten } 2008 \\
(36) \\
\end{array}$} & \multicolumn{2}{|c|}{$\begin{array}{c}\text { Ruetten } 2009 \\
\text { (34) }\end{array}$} & \multicolumn{2}{|c|}{$\begin{array}{c}\text { Ruetten } 2009 \\
\text { (35) }\end{array}$} & \multicolumn{2}{|c|}{$\begin{array}{c}\text { Wang 2011 } \\
(42)\end{array}$} \\
\hline $\begin{array}{l}\text { Study design/ } \\
\text { Level of } \\
\text { evidence }\end{array}$ & \multicolumn{2}{|c|}{ Non-RCT/2b } & \multicolumn{2}{|l|}{$\mathrm{RCT} / 1 \mathrm{~b}$} & \multicolumn{2}{|l|}{$\mathrm{RCT} / 1 \mathrm{~b}$} & \multicolumn{2}{|l|}{$\mathrm{RCT} / 1 \mathrm{~b}$} & \multicolumn{2}{|l|}{$\mathrm{RCT} / 1 \mathrm{~b}$} & \multicolumn{2}{|c|}{ Non-RCT/2b } \\
\hline Surgical site & \multicolumn{2}{|c|}{ Lumbar } & \multicolumn{2}{|l|}{ Cervical } & \multicolumn{2}{|l|}{ Lumbar } & \multicolumn{2}{|c|}{\begin{tabular}{|l}
$\begin{array}{l}\text { Lumbar } \\
\text { (recurrent) }\end{array}$ \\
\end{tabular}} & \multicolumn{2}{|l|}{ Cervical } & \multicolumn{2}{|c|}{$\begin{array}{l}\text { Lumbar } \\
\text { (recurrent) }\end{array}$} \\
\hline $\begin{array}{l}\text { Follow-up } \\
\text { duration }\end{array}$ & \multicolumn{2}{|c|}{34 months } & \multicolumn{2}{|c|}{24 months } & \multicolumn{2}{|c|}{24 months } & \multicolumn{2}{|c|}{24 months } & \multicolumn{2}{|c|}{24 months } & \multicolumn{2}{|c|}{20 months } \\
\hline $\begin{array}{l}\text { Participants } \\
(\mathrm{m}: \mathrm{f})\end{array}$ & \multicolumn{2}{|c|}{$\begin{array}{l}54 \text { patients } \\
(38: 16)\end{array}$} & \multicolumn{2}{|c|}{$\begin{array}{l}200 \text { patients } \\
(68: 132)\end{array}$} & \multicolumn{2}{|c|}{$\begin{array}{l}200 \text { patients } \\
(84: 116)\end{array}$} & \multicolumn{2}{|c|}{$\begin{array}{l}100 \text { patients } \\
(56: 44)\end{array}$} & \multicolumn{2}{|c|}{$\begin{array}{l}120 \text { patients } \\
(43: 77)\end{array}$} & \multicolumn{2}{|c|}{$\begin{array}{l}56 \text { patients } \\
(33: 23)\end{array}$} \\
\hline Age: & \multicolumn{2}{|c|}{$\begin{array}{l}45(26-67) \\
\text { years }\end{array}$} & \multicolumn{2}{|c|}{$43(27-62)$ years } & \multicolumn{2}{|c|}{$43(20-68)$ years } & \multicolumn{2}{|c|}{$39(23-59)$ years } & \multicolumn{2}{|c|}{$(30-61)$ years } & \multicolumn{2}{|c|}{$\begin{array}{l}\text { FE: }(36 \pm 8) \text { days } \\
\text { TDS: }(35 \pm 9) \\
\text { days }\end{array}$} \\
\hline Duration: & \multicolumn{2}{|c|}{$>28$ days } & $94(5-24$ & days & $82(1-48$ & days & $69(1-39$ & ) days & $(4-128) d$ & & $\begin{array}{l}\text { FE: }(69 \\
\text { days } \\
\text { TDS: }(6 \\
\text { days }\end{array}$ & 6) \\
\hline \begin{tabular}{|l}
$\begin{array}{l}\text { Conservative } \\
\text { treatment time }\end{array}$ \\
\end{tabular} & mean: & & $\begin{array}{l}\text { mean: } 10 \\
(171 / 200 \\
\end{array}$ & & $\begin{array}{l}\text { mean: } 9 v \\
(162 / 200 \\
\end{array}$ & & mean: $9 \mathrm{v}$ & $(79 / 100)$ & NA & & NA & \\
\hline $\begin{array}{l}\text { Intervention/ } \\
\text { Comparison }\end{array}$ & $\begin{array}{l}\mathrm{FE}=25 \\
\mathrm{TDS}= \\
(\mathrm{NA})\end{array}$ & & $\begin{array}{l}\mathrm{FE}=100 ; \\
\text { (WOLF) }\end{array}$ & $\mathrm{DS}=100$ & $\begin{array}{l}\mathrm{FE}=100 ; \\
\text { (WOLF) }\end{array}$ & $S=100$ & $\begin{array}{l}\mathrm{FE}=50 ; 7 \\
\text { (WOLF) }\end{array}$ & $S=50$ & $\begin{array}{l}\mathrm{FE}=60 ; \mathrm{TI} \\
\text { (WOLF) }\end{array}$ & $=60$ & $\begin{array}{l}\mathrm{FE}=28 ; \\
\mathrm{TDS}=2 \\
\text { (WOLF }\end{array}$ & \\
\hline & $\begin{array}{l}\text { L4-5: } \\
25\end{array}$ & $\begin{array}{l}\text { L4-5: } \\
29\end{array}$ & $\begin{array}{l}\text { C4-5: } 7 \\
\text { C5-6: } 20 \\
\text { C6-7: } 55 \\
\text { C7-T1: } \\
14\end{array}$ & $\begin{array}{l}\text { C4-5: } 11 \\
\text { C5-6: } 22 \\
\text { C6-7: } 61 \\
\text { C7-T1: } \\
10\end{array}$ & \begin{tabular}{|l|} 
L5-S1: \\
38 \\
L4-5: 33 \\
L3-4: 20 \\
L2-3: 7 \\
L1-2: 2 \\
\end{tabular} & $\begin{array}{l}\text { L5-S1: } \\
\text { 39 } \\
\text { L4-5: } 31 \\
\text { L3-4: } 25 \\
\text { L2-3: } 5 \\
\text { L1-2: } 0\end{array}$ & $\begin{array}{l}\text { L5-S1: } \\
\text { 17 } \\
\text { L4-5: } 24 \\
\text { L3-4: } 6 \\
\text { L2-3: } 3\end{array}$ & $\begin{array}{l}\text { L5-S1: } 21 \\
\text { L4-5: } 18 \\
\text { L3-4: } 10 \\
\text { L2-3: } 1\end{array}$ & $\begin{array}{l}\text { C3-4: } 2 \\
\text { C4-5: } 9 \\
\text { C5-6: } 29 \\
\text { C6-7: } 20 \\
\text { C7-T1: } 2\end{array}$ & $\begin{array}{l}\text { C3-4: } 1 \\
\text { C4-5: } 9 \\
\text { C5-6: } 26 \\
\text { C6-7: } 21 \\
\text { C7-T1: } 3\end{array}$ & $\begin{array}{l}\text { L5-S1: } \\
22 \\
\text { L4-5: } 6\end{array}$ & $\begin{array}{l}\text { L5-S1: } \\
15 \\
\text { L4-5: } \\
13\end{array}$ \\
\hline Outcomes & $\begin{array}{l}\text { VAS s } \\
\text { ODI } \\
\text { impro } \\
\text { Periop } \\
\text { param } \\
\text { MRI/C } \\
\text { X-rays } \\
\text { Comp }\end{array}$ & $\begin{array}{l}\text { es, } \\
\text { ments, } \\
\text { ative } \\
\text { ers, } \\
\text { and } \\
\text { ations }\end{array}$ & $\begin{array}{l}\text { VAS scor } \\
\text { NASS sce } \\
\text { Periopera } \\
\text { paramete } \\
\text { Hilibranc } \\
\text { Complica }\end{array}$ & $\begin{array}{l}\text { s, } \\
\text { ive } \\
\text { s, } \\
\text { criteria, } \\
\text { ions }\end{array}$ & $\begin{array}{l}\text { VAS scor } \\
\text { ODI } \\
\text { improver } \\
\text { NASS sce } \\
\text { Perioper } \\
\text { paramete } \\
\text { Complic }\end{array}$ & $\begin{array}{l}\text { s, } \\
\text { ents, } \\
\text { es, } \\
\text { ive } \\
\text { s, } \\
\text { ions }\end{array}$ & $\begin{array}{l}\text { VAS sco } \\
\text { ODI imp } \\
\text { NASS sc } \\
\text { Perioper } \\
\text { paramet } \\
\text { Complic }\end{array}$ & $\begin{array}{l}\text { s, } \\
\text { ovements, } \\
\text { res, } \\
\text { tive } \\
\text { s, } \\
\text { tions }\end{array}$ & $\begin{array}{l}\text { VAS score } \\
\text { NASS sco } \\
\text { Periopera } \\
\text { parameteI } \\
\text { Hilibrand } \\
\text { MRI/CT a } \\
\text { X-rays, } \\
\text { Complica }\end{array}$ & $\begin{array}{l}\text { es, } \\
\text { ive } \\
\text { criteria, } \\
\text { nd } \\
\text { ions }\end{array}$ & $\begin{array}{l}\text { VAS sc } \\
\text { Periope } \\
\text { parame } \\
\text { Compli }\end{array}$ & $\begin{array}{l}\text { res, } \\
\text { rative } \\
\text { ers, } \\
\text { cations }\end{array}$ \\
\hline
\end{tabular}

Note: RCT: Randomized controlled trial; FE: Full-endoscopic group; TDS: Traditional discectomy group; VAS: Visual analogue scale; ODI: Oswestry disability index; NASS: North American Spine Society Instrument; w: weeks; m:male; f: female; NA: Not available.

foraminotomy approach $(35,41,42), 2$ used an interlaminar or transforaminal pathway $(34,36)$, and one used a transdiscal method (35). In the TDS procedure, 4 trials used microsurgical sequestrectomy $(34,36,41,42)$ and 2 used microsurgical Anterior Cervical Discectomy and Fusion (ACDF) polyetheretherketone (PEEK) cage, no plate) $(35,37)$.

\section{Methodological Quality of Included Studies}

Four RCTs (34-37) provided a moderate level of evidence due to a lack of allocation concealment (Table 2 ), and 2 non-RCTs $(41,42)$ were estimated to be of high quality according to the modified Newcastle-Ottawa scale (Table 3). Overall, the total risk of bias of the included studies is considered moderate.

\section{Quality of Evidence}

The quality of the evidence was evaluated and shown in Table $4(43,44)$. All RCTs were downgraded by one level following the GRADE guidelines (38-40) due to limitations in risk of bias. The RCTs (34-37) were graded as moderate quality. The quality of the nonRCTs $(41,42)$ was not upgraded and denoted as low due to a lack of allocation concealment and the blinding of participants and personnel. Therefore, 2 non-RCTs were considered to provide low-quality evidence. 
Table 2. Bias of risk in randomized controlled trials

\begin{tabular}{|l|c|c|c|c||}
\hline & $\begin{array}{c}\text { Ruetten 2008 } \\
\text { (Cervical) } \\
(\mathbf{3 7})\end{array}$ & $\begin{array}{c}\text { Ruetten 2008 } \\
\text { (Lumbar) } \\
(\mathbf{3 6})\end{array}$ & $\begin{array}{c}\text { Ruetten 2009 } \\
\text { (Cervical) } \\
\mathbf{( 3 5 )}\end{array}$ & $\begin{array}{c}\text { Ruetten 2009 } \\
\text { (Lumbar) } \\
(\mathbf{3 4})\end{array}$ \\
\hline Random sequence generation & Unclear risk & Unclear risk & Low risk & Unclear risk \\
\hline Allocation concealment & High risk & High risk & High risk & High risk \\
\hline Blinding of participants and personnel & High risk & High risk & High risk & High risk \\
\hline Blinding of outcome assessment & Low risk & Low risk & Low risk & Low risk \\
\hline Incomplete outcome data & Low risk & Low risk & Low risk & Low risk \\
\hline Selective reporting & Low risk & Low risk & Low risk & Low risk \\
\hline Other bias & Low risk & Low risk & Low risk & Low risk \\
\hline
\end{tabular}

Table 3. Modified Newcastle-Ottawa Scale (NOS) scores for non-RCT studies

\begin{tabular}{|l|c|c|c|c|}
\hline Study & Selection & Comparability & Outcomes & Quality score \\
\hline Lee 2009 (Lumbar) (41) & 2 & 3 & 2 & 7 \\
\hline Wang 2011 (Lumbar) (42) & 2 & 3 & 2 & 7 \\
\hline
\end{tabular}

Table 4. Grading of clinical studies following GRADE guidelines.

\begin{tabular}{|c|c|c|c|c|c|c|c|c|c|}
\hline References & $\begin{array}{l}\text { Study } \\
\text { design }\end{array}$ & $\begin{array}{c}\text { Risk } \\
\text { of } \\
\text { bias }\end{array}$ & Indirectness & Imprecision & $\begin{array}{c}\text { Publication } \\
\text { bias }\end{array}$ & $\begin{array}{l}\text { Large } \\
\text { effect }\end{array}$ & $\begin{array}{c}\text { Plausible } \\
\text { residual } \\
\text { confounding }\end{array}$ & Total & $\begin{array}{c}\text { Quality } \\
\text { of } \\
\text { evidence }\end{array}$ \\
\hline $\begin{array}{l}\text { Lee } \\
\text { et al } 2009(41)\end{array}$ & Non-RCT & -2 & 0 & 0 & 0 & 0 & 0 & -2 & low \\
\hline $\begin{array}{l}\text { Ruetten } \\
\text { et al } 2008 \text { (36) }\end{array}$ & RCT & -1 & 0 & 0 & 0 & 0 & 0 & -1 & moderate \\
\hline $\begin{array}{l}\text { Ruetten } \\
\text { et al } 2008 \text { (37) }\end{array}$ & RCT & -1 & 0 & 0 & 0 & 0 & 0 & -1 & moderate \\
\hline $\begin{array}{l}\text { Ruetten } \\
\text { et al } 2009 \text { (34) }\end{array}$ & RCT & -1 & 0 & 0 & 0 & 0 & 0 & -1 & moderate \\
\hline $\begin{array}{l}\text { Ruetten } \\
\text { et al } 2009 \text { (35) }\end{array}$ & RCT & -1 & 0 & 0 & 0 & 0 & 0 & -1 & moderate \\
\hline $\begin{array}{l}\text { Wang } \\
\text { et al } 2011 \text { (42) }\end{array}$ & Non-RCT & -2 & 0 & 0 & 0 & 0 & 0 & -2 & low \\
\hline
\end{tabular}

RCT: Randomized controlled trial

\section{Complications}

All included studies reported the outcome of complications with low heterogeneity (Fig. 2). There were 14/363 complications in the FE group and 42/367 complications in the TDS group, and the pooled data indicated a significant difference favoring the FE group (RR: $0.35 ; 95 \% \mathrm{Cl}, 0.19-0.63 ; P<0.001$, Fig. 2). Analyses of the cervical and lumbar subgroups also revealed a lower incidence of complications in both groups (Cervical subgroup: RR: $0.43 ; 95 \% \mathrm{Cl}: 0.15-1.20, P=0.11$; Lumbar subgroup: RR: $0.31 ; 95 \% \mathrm{Cl}: 0.15-0.65, P=$ 0.002; Fig. 2).

\section{Reoperation}

The incidence of reoperation was reported in 5 studies, and the heterogeneity was low (Fig. 3). In the FE group, 25/335 cases required a second operation, compared to 25/339 cases in the TDS group. The incidence of reoperation did not differ significantly between the groups (RR: 1.02; $95 \% \mathrm{Cl}, 0.59-1.75 ; P=0.94$, Fig. 3). In the subgroup analysis, there were no significant differences between the FE group and TDS group (Cervical subgroup: RR: $1.43 ; 95 \% \mathrm{Cl}: 0.56-3.66, P=0.46$; Lumbar subgroup: RR: $0.86 ; 95 \% \mathrm{Cl}: 0.45-1.67, P=0.66$; Fig. 3 ). 
Pain Physician: March/April 2016: 19:103-118

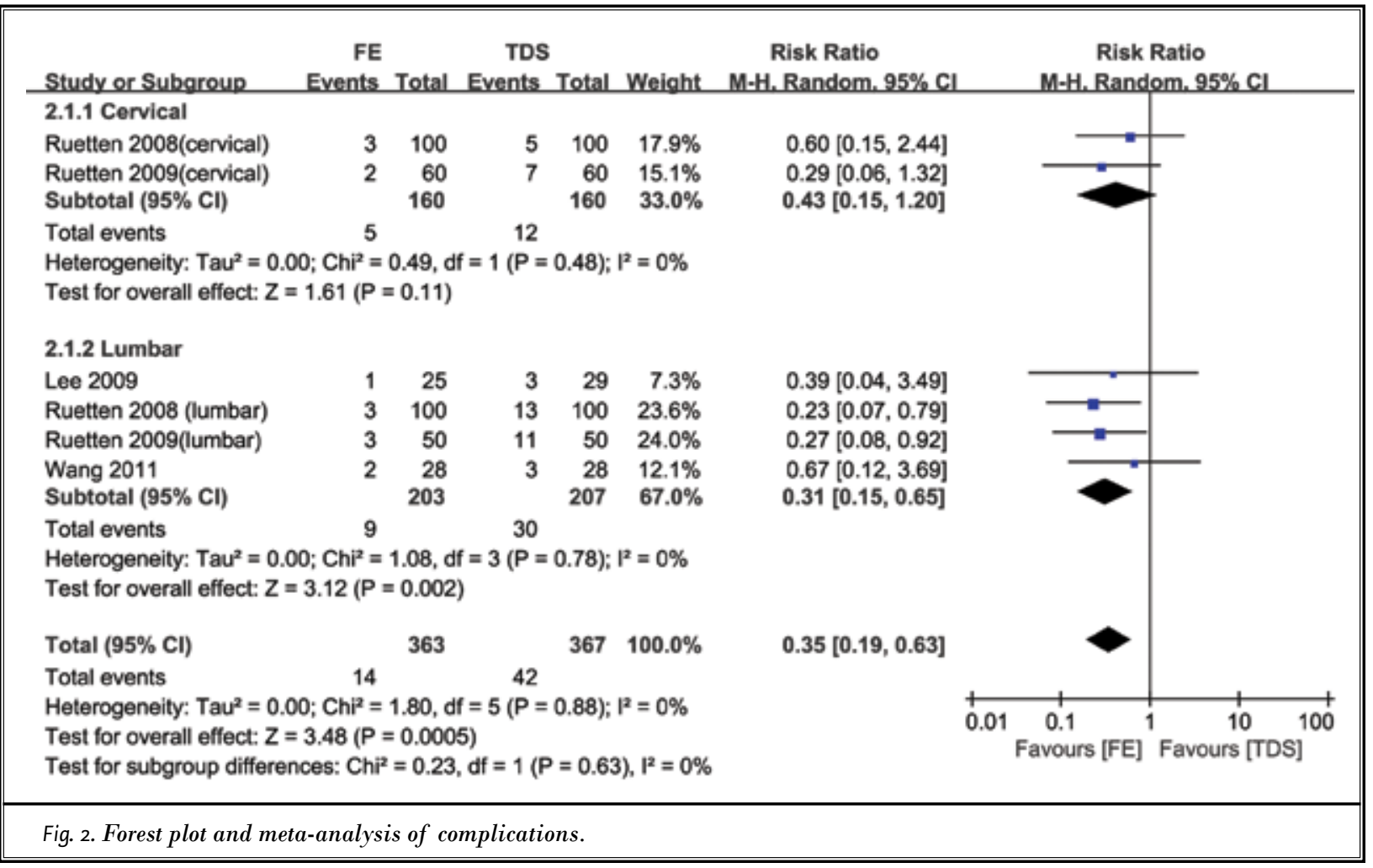

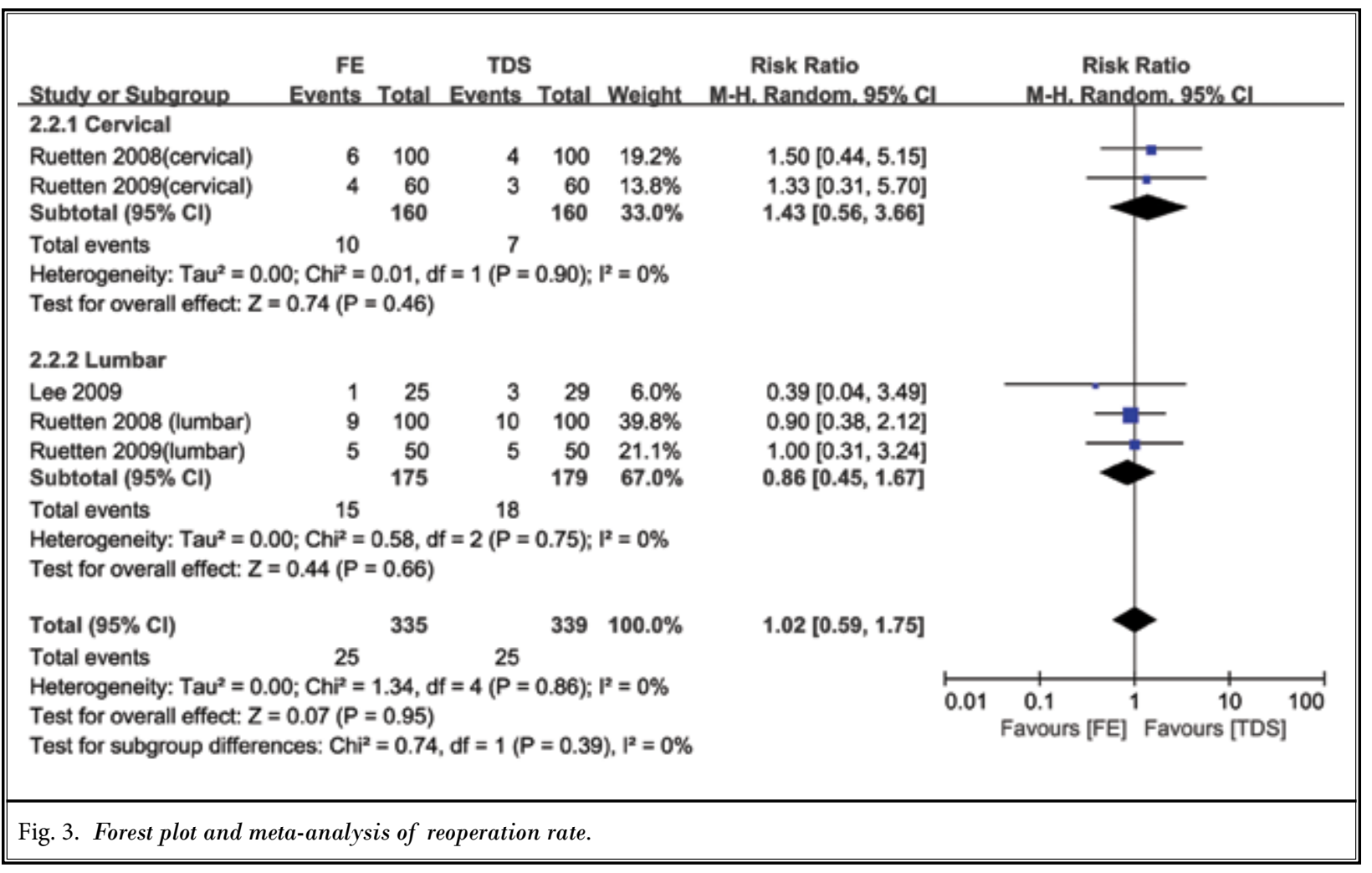




\section{Perioperative Parameters}

All 6 studies reported operation time. The pooled analysis revealed a shorter operation time in both the cervical and lumbar groups (Cervical WMD: $-35.34 ; 95 \%$ Cl: -45.12 - -25.56; $P<0.001$; Lumbar WMD: -18.48; $95 \% \mathrm{Cl}:-33.48--3.47 ; P<0.001 ;$ Table 4, Fig. 4). Five studies reported perioperative blood loss, and pooling the data revealed a statistically significant difference favoring the FE group (Cervical WMD: $-5.00 ; 95 \% \mathrm{Cl}$ : -5.87 - -4.13; $P<0.001$; Lumbar WMD: $-43.48 ; 95 \% \mathrm{Cl}$ : $-54.70--32.25 ; P<0.001$; Table 4, Fig. 4). The hospital stay was published in 3 studies, and the pooled data indicated shorter hospital stays in the FE group (Cervical WMD: $-9.33 ; 95 \% \mathrm{Cl}$ : $20.11-1.44 ; P=0.09$; Lumbar WMD: -12.16 ; $95 \% \mathrm{Cl}$ : $17.24--7.09 ; P<0.001$; Table 4, Fig. 4). Three trials provided the days until return to work, and the results revealed a shorter time in the $\mathrm{FE}$ group (Cervical WMD: $-15.00 ; 95 \% \mathrm{Cl}$ : $-18.87--11.13 ; P$ $<0.001$; Lumbar WMD: -24.00; 95\% Cl: $-28.58--19.42 ; P$ $<0.001$; Table 4, Fig. 4).

\section{Clinical Outcomes}

\section{Clinical Outcomes}

According to the complete depiction of the radicular pain status after 2 years, the clinical outcomes were divided into the following 3 types: no pain, occasional pain, and no improvement. The first 2 results were considered effective clinical outcomes. Pooled analysis of 3 studies including 500 patients revealed no significant differences between the groups (Cervical subgroup: RR: 1.01; $95 \% \mathrm{Cl}: 0.92-1.12, P=0.82$; Lumbar subgroup: RR: $1.05 ; 95 \% \mathrm{Cl}: 1.00-1.10, P=0.05 ;$ Fig. 5, Table 6).

\section{Results of Different Meta-analysis Outcomes of NASS and VAS Scores}

Data were pooled from 4 studies of 620 patients, and the primary results of the overall meta-analyses of the NASS and visual analog scale (VAS) scores are presented in Fig. 6 and Table 5.

The NASS pain score changed in the cervical $(0.08$, $0.20,-0.13,-0.10$, Fig. 6, Table 5) and lumbar groups $(0.03,-0.16,0.13,-0.13$, Fig. 6 , Table 5$)$, but this change was only significant 6 months after therapy in the cervical group ( $P=0.02$, Fig. 6, Table 5).

The NASS neurology score did not significantly change after therapy at any follow-up time points except at 3 months in the lumbar group $(P=0.008$, Fig. 6 , Table 5).

The arm VAS score was reduced at 3 months, 6 months, and 24 months $(-0.91,-0.93,-1.53$, Fig. 6, Table 5) but increased at 12 months (1.91, Fig. 6, Table 5). However, only change in the VAS score at 24 months was statistically significant $(P=0.002$, Fig. 6 , Table 5$)$. The leg VAS score was reduced at all follow-up time points, but none of these changes were significant (Fig. 6, Table 5).

The VAS scores in the neck $(-2.86,-2.50,-2.00,-0.09$, Fig. 6, Table 5) and back (-2.20, $-2.63,-0.83,-1.98$, Fig. 6, Table 5) were both reduced after therapy at 3 months, 6 months, 12 months, and 24 months, and this reduction was significant in the cervical group at 3 months, 6 months, and 12 months $(P=0.003, P=0.006, P=0.01$, Fig. 6, Table 5) and in the lumbar group at 3 months and 6 months $(P=0.01, P=0.004$, Fig 6 , Table 5).

\section{Results of Different Meta-analyses of Hilibrand Criteria and Oswestry Disability Index Improvement}

Two trials reported Hilibrand criteria in cervical operations. The pooled analysis revealed no significant difference between the FE and TDS groups at 3 months, 6 months, 12 months, and 24 months (RR: 1.02, RR: 1.01, RR: 1.04, RR: 1.02, Fig. 7, Table 6). Oswestry Disability Index (ODI) improvement was increased at 3 months, 12 months, and 24 months after therapy $(0.06,0.37,1.60$, Fig. 7, Table 6 ) but was reduced at 6 months (-1.51, Fig. 7, Table 6). None of these changes were statistically significant at any follow-up time point.

\section{Others}

Only one study reported postoperative lumbar vertebral instability, and the results revealed no significant difference between the groups (OR: $0.37 ; 95 \% \mathrm{Cl}: 0.01$ $-9.65, P=0.55$, Table 6). Twelve patients in cervical operations exhibited progression of pre-existing adjacent disc degeneration $(9 \times \mathrm{TDS}=18.8 \% ; 3 \times \mathrm{FE}=5.9 \%$, not significant).

\section{Discussion}

The FE technique was first used in the clinic more than 8 years ago $(45,46)$. Although there have been many publications on endoscopic spine surgery, few controlled studies are available comparing the modern FE procedure to TDS (21). In addition, few review articles about this topic were identified because most of the relevant studies in this field have only recently been published (21).

This systematic review and meta-analysis presents an integrated overview comparing recent studies on 
Pain Physician: March/April 2016: 19:103-118

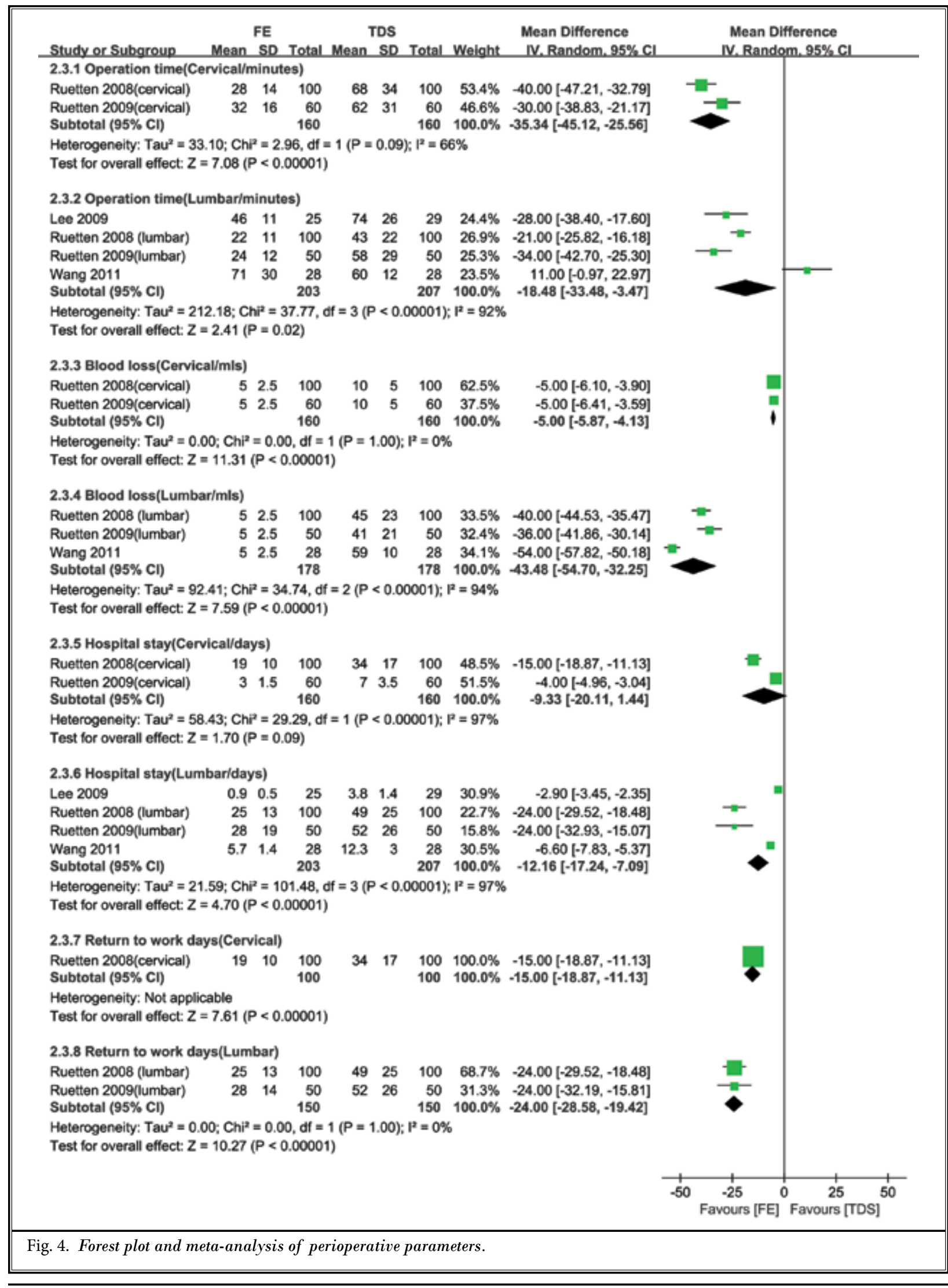


Full-Endoscopic Procedures Versus Traditional Discectomy Surgery

Table 5. The results of different meta-analysis outcomes for NASS and VAS scores.

\begin{tabular}{|c|c|c|c|c|c|}
\hline Outcomes & $\mathbf{N}$ & $\mathbf{n}$ & Effect estimates & $\boldsymbol{P}$ & Heterogeneity test \\
\hline \multicolumn{6}{|l|}{ NASS neurology } \\
\hline 3 months (Cervical) & 2 & 320 & $0.08(-0.10,0.27)$ & 0.39 & $\mathrm{P}=0.05, \mathrm{I} 2=73 \%$ \\
\hline 3 months (Lumbar) & 2 & 300 & $0.03(-0.20,0.26)$ & 0.79 & $\mathrm{P}=0.69, \mathrm{I} 2=0 \%$ \\
\hline 6 months (Cervical) & 2 & 320 & $0.20(0.02,0.38)$ & 0.03 & $\mathrm{P}=1.00, \mathrm{I} 2=0 \%$ \\
\hline 6 months(Lumbar) & 2 & 300 & $-0.16(-0.40,0.07)$ & 0.17 & $\mathrm{P}=0.69, \mathrm{I} 2=0 \%$ \\
\hline 12 months (Cervical) & 2 & 320 & $-0.13(-0.02,0.29)$ & 0.09 & $\mathrm{P}=0.55, \mathrm{I} 2=0 \%$ \\
\hline 12 months(Lumbar) & 2 & 300 & $0.13(-0.08,0.34)$ & 0.22 & $\mathrm{P}=0.23, \mathrm{I} 2=30 \%$ \\
\hline 24 months (Cervical) & 2 & 320 & $0.08(-0.11,0.28)$ & 0.40 & $\mathrm{P}=0.27, \mathrm{I} 2=18 \%$ \\
\hline 24 months(Lumbar) & 2 & 300 & $0.20(-0.04,0.44)$ & 0.11 & $\mathrm{P}=1.00, \mathrm{I} 2=0 \%$ \\
\hline \multicolumn{6}{|l|}{ NASS pain } \\
\hline 3 months (Cervical) & 2 & 320 & $-0.18(-0.38,0.01)$ & 0.06 & $\mathrm{P}=0.22, \mathrm{I} 2=34 \%$ \\
\hline 3 months (Lumbar) & 2 & 300 & $-0.32(-0.57,-0.08)$ & 0.008 & $\mathrm{P}=0.43, \mathrm{I} 2=0 \%$ \\
\hline 6 months (Cervical) & 2 & 320 & $-0.05(-0.35,0.24)$ & 0.72 & $\mathrm{P}=0.09, \mathrm{I} 2=66 \%$ \\
\hline 6 months(Lumbar) & 2 & 300 & $-0.26(-0.56,0.03)$ & 0.08 & $\mathrm{P}=0.24, \mathrm{I} 2=28 \%$ \\
\hline 12 months (Cervical) & 2 & 320 & $-0.07(-0.25,0.10)$ & 0.41 & $\mathrm{P}=0.03, \mathrm{I} 2=79 \%$ \\
\hline 12 months(Lumbar) & 2 & 300 & $-0.16(-0.41,0.09)$ & 0.21 & $\mathrm{P}=0.71, \mathrm{I} 2=0 \%$ \\
\hline 24 months (Cervical) & 2 & 320 & $-0.10(-0.26,0.06)$ & 0.22 & $\mathrm{P}=100, \mathrm{I} 2=0 \%$ \\
\hline 24 months(Lumbar) & 2 & 300 & $-0.13(-0.39,0.13)$ & 0.32 & $\mathrm{P}=0.46, \mathrm{I} 2=0 \%$ \\
\hline \multicolumn{6}{|l|}{ VAS score in arm/leg } \\
\hline 3 months (Arm) & 2 & 320 & $-0.91(-4.82,3.01)$ & 0.65 & $\mathrm{P}=0.002, \mathrm{I} 2=89 \%$ \\
\hline 3 months (Leg) & 2 & 300 & $-3.19(-4.07,-2.31)$ & $<0.001$ & $\mathrm{P}=0.38, \mathrm{I} 2=0 \%$ \\
\hline 6 months (Arm) & 2 & 320 & $-0.93(-4.85,2.99)$ & 0.64 & $\mathrm{P}<0.001, \mathrm{I} 2=93 \%$ \\
\hline 6 months(Leg) & 2 & 300 & $0.12(-3.79,4.03)$ & 0.95 & $\mathrm{P}=0.001, \mathrm{I} 2=91 \%$ \\
\hline 12 months (Arm) & 2 & 320 & $1.91(-0.04,3.86)$ & 0.06 & $\mathrm{P}=0.05, \mathrm{I} 2=75 \%$ \\
\hline 12 months(Leg) & 2 & 300 & $-0.10(-4.02,3.81)$ & 0.96 & $\mathrm{P}=0.002, \mathrm{I} 2=90 \%$ \\
\hline 24 months (Arm) & 2 & 320 & $-1.53(-2.51,-0.55)$ & 0.002 & $\mathrm{P}=0.29, \mathrm{I} 2=12 \%$ \\
\hline 24 months(Leg) & 4 & 410 & $-0.58(-1.46,0.29)$ & 0.19 & $\mathrm{P}=0.15, \mathrm{I} 2=44 \%$ \\
\hline \multicolumn{6}{|l|}{ VAS score in neck/back } \\
\hline 3 months (Neck) & 2 & 320 & $-2.86(-4.74,-0.97)$ & 0.003 & $\mathrm{P}=0.13, \mathrm{I} 2=57 \%$ \\
\hline 3 months (Back) & 2 & 300 & $-2.20(-3.94,-0.45)$ & 0.01 & $\mathrm{P}<0.001, \mathrm{I} 2=91 \%$ \\
\hline 6 months (Neck) & 2 & 320 & $-2.50(-4.28,-0.71)$ & 0.006 & $\mathrm{P}=0.58, \mathrm{I} 2=0 \%$ \\
\hline 6 months(Back) & 2 & 300 & $-2.63(-4.39,-0.86)$ & 0.004 & $\mathrm{P}<0.001, \mathrm{I} 2=91 \%$ \\
\hline 12 months (Neck) & 2 & 320 & $-2.00(-3.56,-0.44)$ & 0.01 & $\mathrm{P}=1.00, \mathrm{I} 2=0 \%$ \\
\hline 12 months(Back) & 2 & 300 & $-0.83(-2.67,1.01)$ & 0.38 & $\mathrm{P}=0.12, \mathrm{I} 2=59 \%$ \\
\hline 24 months (Neck) & 2 & 320 & $-0.09(-2.04,1.86)$ & 0.93 & $\mathrm{P}=0.24, \mathrm{I} 2=27 \%$ \\
\hline 24 months(Back) & 4 & 410 & $-1.98(-6.36,2.40)$ & 0.38 & $\mathrm{P}<0.001, \mathrm{I} 2=93 \%$ \\
\hline
\end{tabular}

VAS: Visual analogue scale; NASS: German version of the North American Spine Society Instrument; N=numbers of trials; $n=$ numbers of cases

the efficacy and safety of FE and TDS in surgical discectomy. Six trials comprising 730 patients were included and analyzed. Overall the quality of the literature was moderate, including 4 Grade I levels of evidence (4 RCTs) and 2 Grade II levels ( 2 non-RCTs).

Although the number of studies included in this analysis was small and our data are not sufficient to demonstrate the superior clinical effectiveness of $\mathrm{FE}$ over TDS, the results at least indicate the lack of evidence on this issue. Furthermore, there is an absence of strong evidence to support clinical applications. Although the included sample size was not large because 


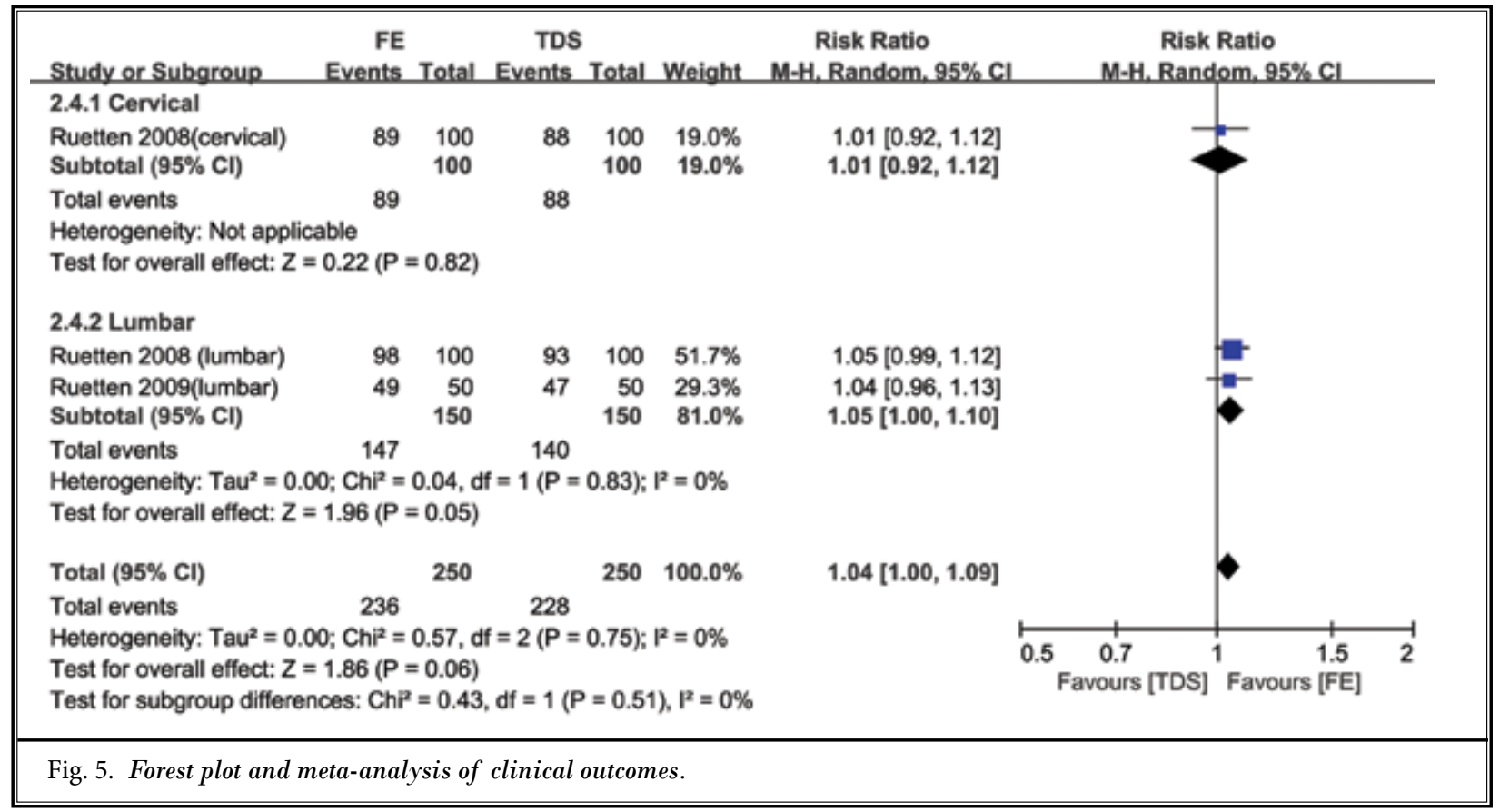

Table 6. The results of different meta-analysis outcomes.

\begin{tabular}{|l|c|c|c|c|c||}
\hline \multicolumn{1}{|c|}{ Outcomes } & N & n & Effect estimates & P & Heterogeneity test \\
\hline ODI improvements (Lumbar) & 2 & 300 & $0.06(-10.68,10.81)$ & 0.99 & $\mathrm{P}=0.01, \mathrm{I} 2=85 \%$ \\
\hline 3 months & 2 & 300 & $-1.51(-14.76,12.47)$ & 0.87 & $\mathrm{P}=0.05, \mathrm{I} 2=74 \%$ \\
\hline 6 months & 2 & 300 & $0.37(-14.23,14.97)$ & 0.96 & $\mathrm{P}=0.04, \mathrm{I} 2=77 \%$ \\
\hline 12 months & 3 & 354 & $1.60(-5.17,8.38)$ & 0.64 & $\mathrm{P}=0.28, \mathrm{I} 2=21 \%$ \\
\hline 24 months & 1 & 54 & $0.37(0.01,9.56)$ & 0.55 & $\mathrm{NA}$ \\
\hline Instability (X-ray) & & & & $\mathrm{P}=0.50, \mathrm{I} 2=0 \%$ \\
\hline Hilibrand criteria (Cervical) & 2 & 290 & $1.02(0.97,1.06)$ & 0.45 & $\mathrm{P}=0.87, \mathrm{I} 2=0 \%$ \\
\hline 3 months & 2 & 289 & $1.01(0.96,1.06)$ & 0.66 & $\mathrm{P}=0.48, \mathrm{I} 2=0 \%$ \\
\hline 6 months & 2 & 286 & $1.04(0.98,1.09)$ & 0.19 & $\mathrm{P}=0.73, \mathrm{I} 2=0 \%$ \\
\hline 12 months & 2 & 274 & $1.02(0.46,2.29)$ & 0.29 & $\mathrm{P}=0.51, \mathrm{I} 2=0 \%$ \\
\hline 24 months & 3 & 500 & $1.80(0.93,3.45)$ & 0.08 & \\
\hline Clinical result &
\end{tabular}

ODI: Oswestry disability index; $N=$ numbers of trials; $n=$ numbers of cases

this is a relatively new technology, our conclusions are supported by the comprehensive evidence of credible outcomes from 730 cases in clinical trials. Therefore, the results of our meta-analysis are credible.

Although we have not provided a systematic and complete evaluation index for comparing the FE and TDS procedures, the main aspects of the clinical application were all included. In particular, as a new type of technology, our major concerns are the assessment of safety. Based on data from 6 trials including 730 patients and of low heterogeneity (Fig. 2), our analysis indicated a reduced incidence of complications in the FE group $(14 / 363 ; 3.86 \%)$ compared to the TDS group $(42 / 367,11.4 \%)$. The subgroup analyses of the cervical ( 2 trials) and lumbar (4 trials) groups were also similar. In addition, the incidence of reoperation reported in 5 studies also showed no significant difference between the groups in the incidence of reoperation (FE group: 


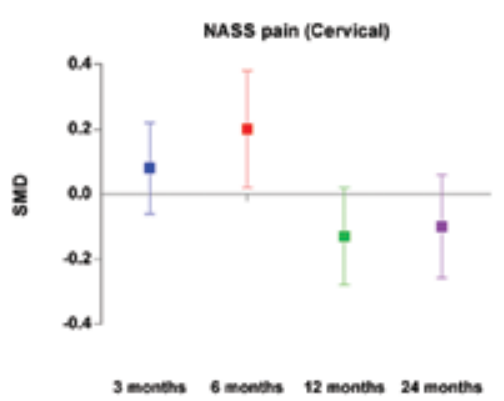

A

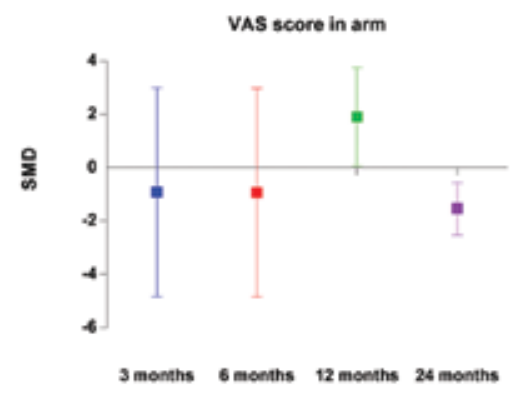

C

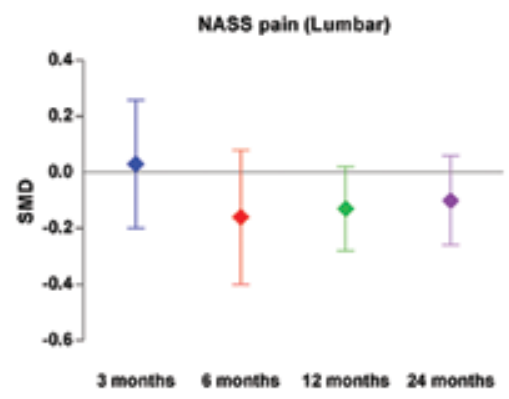

E

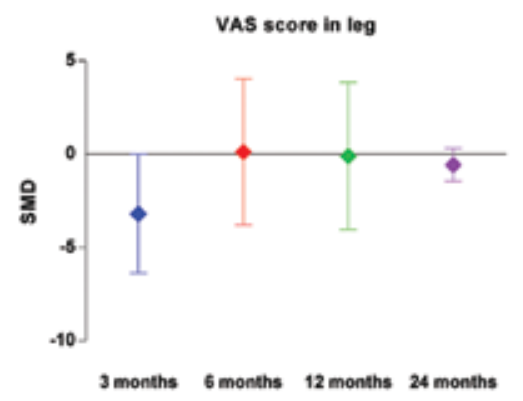

G

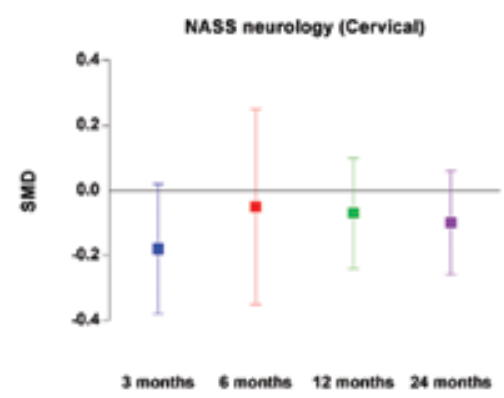

B

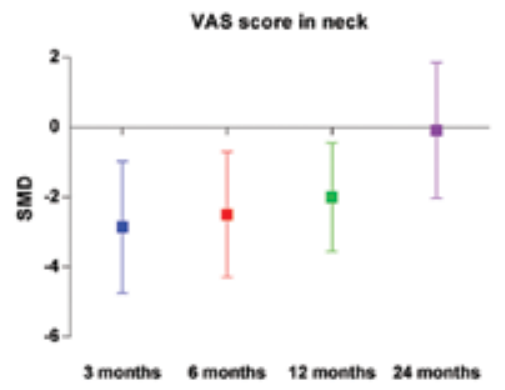

D
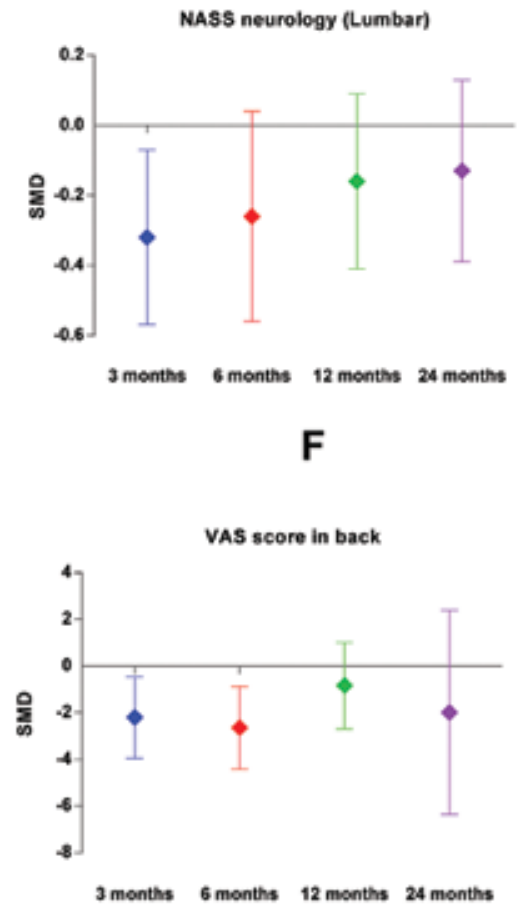

H

Fig. 6. Dynamic results of different meta-analysis outcomes of NASS and VAS scores. 


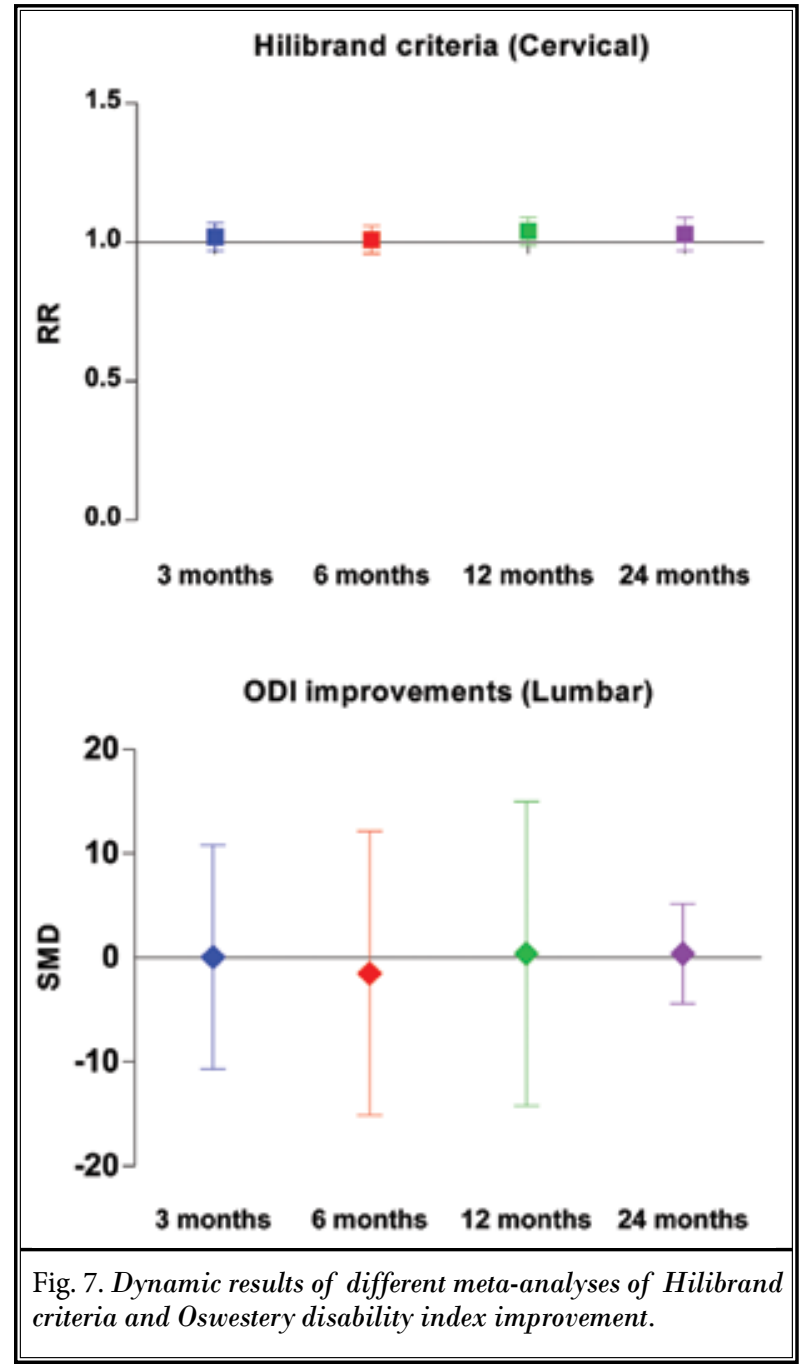

25/335; TDS group: 25/339. RR: 1.02; $P=0.94$, Fig. 3). In the subgroup analyses, there were also no significant differences between the FE group and TDS group (cervical subgroup: RR: $1.43 ; P=0.46$; lumbar subgroup: RR: 0.86 ; $P=0.66$; Fig. 3 ). In a word, there is accumulating data to support minimally invasive spine surgery techniques (47-51), and these data may factor into the decision of when to use these techniques.

The comparison of perioperative parameters revealed significantly less blood loss $(P<0.001)$ and shorter operation times $(P<0.05)$ in the FE group compared to the TDS group (in both the cervical and lumbar subgroups). In addition, the FE procedure allows patients to leave the hospital sooner and return to work faster than the TDS procedure ( $P<0.05$ in all groups). These outcomes may reflect the incisions and muscle dissection involved in the procedures. The FE equipment is inserted through the paraspinal musculature directly over the targeted segment (52).

Clinical results were evaluated in 3 trials, and no significant differences in clinical efficacy between FE and TDS were identified. Moreover, this meta-analysis provides a dynamic detailed comparison of results, which is more convincing than merely contrasting end-point events. Although our data did not provide a definitive conclusion about which procedure is better or worse, the trend of the comparison result could be extrapolated and provide some useful evidence. For the NASS neurology, although a statistically significant reduction was only observed in the cervical subgroup at 6 months, there was evidence of a trend of higher scores for the FE procedure compared with the TDS procedure. Similarly, a trend of lower pain scores was observed in the FE group compared to the TDS group for both the cervical and lumbar NASS and VAS pain scores. In the cervical group, the Hilibrand criteria were used to evaluate efficacy in the 2 groups, and no differences were identified. In the lumbar group, there was also no difference in ODI improvement. Moreover, there were no differences in lumbar vertebral instability and adjacent disc degeneration, which may indicate that the FE surgical procedure can obtain a clinical outcome as effective as conventional open surgery (53-55).

We also searched systematic reviews and metaanalyses comparing minimally invasive discectomy to open discectomy $(12,14,16-18,56)$. Most of the articles identified focused on microendoscopic discectomy and tubular discectomy. Of the 6 publications included in our study, 3 articles included one FE study, one included 2 studies, and one included 3 studies. None of the studies were about the FE procedure as a new technique being used in the clinic alone. This suggests a lack of evidence-based research. In our study, the 6 articles were all published within the last 3 years, which may indicate that minimally invasive discectomy is on the rise in clinical application.

This meta-analysis also has limitations. First, only 6 studies were included, and 4 of these had the same authors because of a lack of published literature. Second, in 4 clinical trials, the SD was estimated as half the mean of the clinical results for perioperative parameters, VAS and NASS, but this estimate did not affect the primary results. Third, some of the studies did not use the same surgical approach, but for this meta-analysis, the FE or TDS approaches were assumed to be similar. Finally, some between-study heterogeneity may be attributable to socioeconomic factors, nutrition, and matching 
Table 7. Systematic review and meta-analysis of minimally invasive discectomy vs open discectomy.

\begin{tabular}{|c|c|c|c|c|c|c|c|c|}
\hline \multirow[t]{2}{*}{ Author } & \multirow[t]{2}{*}{ Year } & \multirow{2}{*}{$\begin{array}{c}\text { Publication } \\
\text { type }\end{array}$} & \multirow[t]{2}{*}{$\mathbf{N}$} & \multirow[t]{2}{*}{$\mathbf{n}$} & \multirow[t]{2}{*}{ Patient } & \multicolumn{2}{|c|}{$\begin{array}{l}\text { Intervention and } \\
\text { Comparison }\end{array}$} & \multirow[t]{2}{*}{ Outcome } \\
\hline & & & & & & MID & OD & \\
\hline $\begin{array}{l}\text { Dasenbrock } \\
\text { et al } \\
(14)\end{array}$ & 2012 & $M$ & 6 & 837 & $\mathrm{DH}$ & $\begin{array}{l}\mathrm{FE}(1) \\
\operatorname{MED}(3) \\
\operatorname{TUB}(2)\end{array}$ & 6 & $\begin{array}{l}\text { Current evidence suggests that both } \\
\text { OD and MID lead to a substantial and } \\
\text { equivalent long-term improvement in leg } \\
\text { pain. Adequate decompression may be the } \\
\text { primary determinant of pain relief. Incidental } \\
\text { durotomies occurred significantly more } \\
\text { frequently during MID, but total complications } \\
\text { did not differ between the techniques. }\end{array}$ \\
\hline $\begin{array}{l}\text { Rasouli et al } \\
(18)\end{array}$ & 2014 & $\begin{array}{l}\text { Cochrane } \\
\text { review }\end{array}$ & 11 & 1172 & LDH & $\begin{array}{l}\text { FE (1) } \\
\text { MED (4) } \\
\text { TUB (3) } \\
\text { Others (3) }\end{array}$ & 11 & $\begin{array}{l}\text { MID may be inferior in terms of relief of leg } \\
\text { pain, LBP, and re-hospitalization; however, } \\
\text { the differences in pain relief appeared to be } \\
\text { small and may not be clinically important. The } \\
\text { potential advantages of MID are lower risk of } \\
\text { surgical site and other infections. MID may be } \\
\text { associated with shorter hospital stay, but the } \\
\text { evidence was inconsistent. }\end{array}$ \\
\hline \begin{tabular}{|l} 
Kamper et al \\
$(17)$
\end{tabular} & 2014 & $S$ and $M$ & 29 & 4472 & LDH & $\begin{array}{l}\text { FE (2) } \\
\text { Others (27) }\end{array}$ & 29 & $\begin{array}{l}\text { There is moderate to low quality evidence of } \\
\text { no differences in clinical outcomes between } \\
\text { MI surgery and conventional microdiscectomy } \\
\text { for LDH patients. }\end{array}$ \\
\hline \begin{tabular}{|l} 
Evaniew et al \\
$(12)$
\end{tabular} & 2014 & $S$ and $M$ & 14 & 1590 & $\mathrm{DH}$ & $\begin{array}{l}\text { FE (3) } \\
\operatorname{MED}(4) \\
\text { TUB (7) }\end{array}$ & 14 & $\begin{array}{l}\text { Current evidence does not support the routine } \\
\text { use of minimally invasive surgery for cervical } \\
\text { or lumbar discectomy. Well-designed trials are } \\
\text { needed given the lack of high-quality evidence. }\end{array}$ \\
\hline $\begin{array}{l}\text { Eichen et al } \\
(56)\end{array}$ & 2014 & $S$ and $M$ & 27 & 3211 & $\mathrm{DH}$ & $\begin{array}{l}\text { FE (0) } \\
\text { Others (27) }\end{array}$ & 27 & $\begin{array}{l}\text { Nucleoplasty reduces pain long term and } \\
\text { improves patients' functional mobility. It is an } \\
\text { effective, low-complication, minimally invasive } \\
\text { procedure used to treat disc herniations. }\end{array}$ \\
\hline $\begin{array}{l}\text { Chang et al } \\
(16)\end{array}$ & 2014 & M & 16 & 2139 & LDH & $\begin{array}{l}\text { FE (1) } \\
\text { MED (6) } \\
\text { Others (9) }\end{array}$ & 16 & $\begin{array}{l}\text { MID results in less suffering for patients during } \\
\text { the hospital course with a similar clinical } \\
\text { efficacy compared to OD. However, greater } \\
\text { effort is required to reduce disc herniation } \\
\text { recurrence to popularize MID. }\end{array}$ \\
\hline
\end{tabular}

S: Systematic Review; M: Meta-analysis; TUB: Tubular discectomy; MED: Microendoscopic discectomy; FE: Full-endoscopic discectomy; DH: Disc herniation; LDH: Lumbar disc herniation; LBP: low back pain; MID: Minimally invasive discectomy; OD: open discectomy.

criteria. These differences might be reduced by using a random-effects model but may not abolish it.

\section{Conclusion}

Based on this systematic review and meta-analysis of 24 months of safety and efficacy in clinical application, we conclude that the FE procedure is as effective as TDS but has the additional benefits of fewer complications and superior perioperative parameters. However, large-volume, well-designed RCTs with extensive follow-up are needed to confirm and update the findings of this analysis.

\section{Author Contribution}

Drs. LXC, ZCF, and DGB had full access to all data in the study and take responsibility for the integrity of the data and the accuracy of the data analysis. Drs. LXC and LRW designed the study protocol. Dr. HCM managed the literature searches and summaries of previous related work and wrote the first draft of the manuscript. Drs. LXC, ZCF, and HCM provided revisions of intellectual content and final approval of the manuscript. 


\section{References}

1. Ganey TM, Meisel HJ. A potential role for cell-based therapeutics in the treatment of intervertebral disc herniation. Eur Spine J 2002; 11:S206-S214.

2. Hogg-Johnson S, van der Velde G, Carroll LJ, Holm LW, Cassidy JD, Guzman J, Cote P, Haldeman S, Ammendolia C, Carragee E, Hurwitz E, Nordin M, Peloso $P$. The burden and determinants of neck pain in the general population: Results of the Bone and Joint Decade 2000-2010 Task Force on Neck Pain and Its Associated Disorders. Spine (Phila Pa 1976) 2008; 33:S39-S51.

3. Cenic A, Kachur E. Lumbar discectomy: A national survey of neurosurgeons and literature review. Can J Neurol Sci 2009; 36:196-200.

4. Vos T, Flaxman AD, Naghavi M, Lozano R, Michaud C, Ezzati M, Shibuya K, Salomon JA, Abdalla S, Aboyans V, Abraham J, Ackerman I, Aggarwal R, Ahn SY, Ali MK, Alvarado M, Anderson HR, Anderson LM, Andrews KG, Atkinson C, Baddour LM, Bahalim AN, Barker-Collo S, Barrero LH, Bartels DH, Basanez MG, Baxter A, Bell ML, Benjamin EJ, Bennett $D$, Bernabe $E$, Bhalla $K$, Bhandari B, Bikbov B, Bin Abdulhak A, Birbeck G, Black JA, Blencowe $H$, Blore JD, Blyth $\mathrm{F}$, Bolliger I, Bonaventure A, Boufous $S$, Bourne R, Boussinesq $M$, Braithwaite $T$, Brayne $C$, Bridgett $L$, Brooker $S$, Brooks P, Brugha TS, Bryan-Hancock C, Bucello C, Buchbinder R, Buckle G, Budke CM, Burch M, Burney $P$, Burstein R, Calabria B, Campbell B, Canter $\mathrm{CE}$, Carabin H, Carapetis J, Carmona L, Cella C, Charlson F, Chen H, Cheng AT, Chou D, Chugh SS, Coffeng LE, Colan $\mathrm{SD}$, Colquhoun S, Colson KE, Condon J, Connor MD, Cooper LT, Corriere M, Cortinovis M, de Vaccaro KC, Couser W, Cowie BC, Criqui MH, Cross M, Dabhadkar KC, Dahiya M, Dahodwala N, Damsere-Derry J, Danaei G, Davis A, De Leo D, Degenhardt L, Dellavalle R, Delossantos A, JDenenberg J, Derrett $S$, Des Jarlais DC, Dharmaratne SD, Dherani M, Diaz-Torne C, Dolk H, Dorsey ER, Driscoll T, Duber H, Ebel B, Edmond K, Elbaz A, Ali SE, Erskine H, Erwin PJ, Espindola $\mathrm{P}$, Ewoigbokhan SE, Farzadfar $\mathrm{F}$, Feigin $V$, Felson DT, Ferrari A, Ferri CP, Fevre EM, Finucane MM, Flaxman $S$, Flood L, Foreman K, Forouzanfar MH, Fowkes FG, Franklin R, Fransen M, Freeman MK,Gabbe BJ, Gabriel SE, Gakidou E, Ganatra HA, Garcia B, Gaspari F, Gillum RF, Gmel G, Gosselin R, Grainger
R, Groeger J, Guillemin F, Gunnell D, Gupta R, Haagsma J, Hagan $H$, Halasa YA, Hall W, Haring D, Haro JM, Harrison JE, Havmoeller R, Hay RJ, Higashi H, Hill C, Hoen B, Hoffman H, Hotez PJ, Hoy $D$, Huang J), Ibeanusi SE, Jacobsen $\mathrm{KH}$, James SL, Jarvis D, Jasrasaria R, Jayaraman S, Johns N, Jonas JB, Karthikeyan G, Kassebaum N, Kawakami N, Keren A, Khoo JP, King CH, Knowlton LM, Kobusingye $\mathrm{O}$, Koranteng $\mathrm{A}$, Krishnamurthi $\mathrm{R}$, Lalloo R, Laslett LL, Lathlean T, Leasher JL, Lee YY, Leigh J, Lim SS, Limb E, Lin JK, Lipnick M, Lipshultz SE, Liu W, Loane M, Ohno SL, Lyons R, Ma J, Mabweijano J, Maclntyre MF, Malekzadeh R, Mallinger L, Manivannan S, Marcenes W, March L, Margolis DJ, Marks GB, Marks R, Matsumori A, Matzopoulos R, Mayosi BM, McAnulty JH, McDermott MM, McGill N, McGrath J), Medina-Mora ME, Meltzer M, Mensah GA, Merriman TR, Meyer AC, Miglioli V, Miller M, Miller TR, Mitchell PB, Mocumbi AO, Moffitt TE, Mokdad AA, Monasta L, Montico M, Moradi-Lakeh M, Moran A, Morawska L, Mori R, Murdoch ME, Mwaniki MK, Naidoo K, Nair MN, Naldi L, Narayan KM, Nelson PK, Nelson RG, Nevitt MC, Newton CR, Nolte $S$, Norman $P$, Norman R, O'Donnell M, O'Hanlon S, Olives C, Omer SB, Ortblad K, Osborne R, Ozgediz R, Page A, Pahari B, Pandian JD, Rivero AP, Patten SB, Pearce N, Padilla RP, Perez-Ruiz F, Perico N, Pesudovs K, Phillips D, Phillips MR, Pierce K, Pion S, Polanczyk GV, Polinder S, Pope CA, 3rd, Popova S, Porrini E, Pourmalek F, Prince $M$, Pullan RL, Ramaiah KD, Ranganathan D, Razavi H, Regan M, Rehm JT, Rein DB, Remuzzi G, Richardson K, Rivara FP, Roberts T, Robinson C, De Leon FR, Ronfani L, Room R, Rosenfeld LC, Rushton L, Sacco RL, Saha S, Sampson U, Sanchez-Riera L, Sanman E, Schwebel DC, Scott JG, Segui-Gomez M, Shahraz S, Shepard DS, Shin H, Shivakoti R, Singh $D$, Singh GM, Singh JA, Singleton J, Sleet DA, Sliwa K, Smith E, Smith JL, Stapelberg NJ, Steer A, Steiner T, Stolk WA, Stovner LJ, Sudfeld C, Syed S, Tamburlini G, Tavakkoli M, Taylor HR, Taylor JA, Taylor WJ, Thomas B, Thomson WM, Thurston GD, Tleyjeh IM, Tonelli M, Towbin JA, Truelsen T, Tsilimbaris MK, Ubeda C, Undurraga EA, van der Werf MJ, van Os J, Vavilala MS, Venketasubramanian $\mathrm{N}$, Wang $\mathrm{M}$, Wang $\mathrm{W}$, Watt $\mathrm{K}$, Weatherall DJ, Weinstock MA, Weintraub R, Weisskopf MG, Weissman MM, White
RA, Whiteford H, Wiersma ST, Wilkinson JD, Williams HC, Williams SR, Witt E, Wolfe F, Woolf AD, Wulf S, Yeh PH, Zaidi AK, Zheng ZJ, Zonies D, Lopez AD, Murray CJ, AlMazroa MA, Memish ZA. Years lived with disability (YLDs) for 1160 sequelae of 289 diseases and injuries 1990-2010: A systematic analysis for the Global Burden of Disease Study 2010. Lancet (London, England) 2012; 380:2163-2196.

5. Weinstein JN, Lurie JD, Tosteson TD, Skinner JS, Hanscom B, Tosteson AN, Herkowitz $\mathrm{H}$, Fischgrund J, Cammisa FP, Albert T, Deyo RA. Surgical vs nonoperative treatment for lumbar disk herniation: The Spine Patient Outcomes Research Trial (SPORT) observational cohort. JAMA 2006; 296:2451-2459.

6. Boselie TF, Willems PC, van Mameren $\mathrm{H}$, de Bie RA, Benzel EC, van Santbrink $H$. Arthroplasty versus fusion in singlelevel cervical degenerative disc disease: A Cochrane review. Spine (Phila Pa 1976) 2013; 38:E1096-E1107.

7. Wang J, Zhou Y, Zhang ZF, Li CQ, Zheng WJ, Liu J. Minimally invasive or open transforaminal lumbar interbody fusion as revision surgery for patients previously treated by open discectomy and decompression of the lumbar spine. Eur Spine ] 2011; 20:623-628.

8. Tian NF, Wu YS, Zhang XL, Xu HZ, Chi $Y L$, Mao FM. Minimally invasive versus open transforaminal lumbar interbody fusion: A meta-analysis based on the current evidence. Eur Spine J 2013; 22:1741-1749.

9. Goldstein CL, Macwan K, Sundararajan K, Rampersaud YR. Comparative outcomes of minimally invasive surgery for posterior lumbar fusion: A systematic review. Clin Orthop Relat Res 2014; 472:1727-1737.

10. Pan L, Zhang P, Yin Q. Comparison of tissue damages caused by endoscopic lumbar discectomy and traditional lumbar discectomy: A randomised controlled trial. Int J Surg 2014; 12:534-537.

11. Wang J, Zhou Y, Feng Zhang Z, Qing Li C, Jie Zheng W, Liu J. Comparison of the clinical outcome in overweight or obese patients after minimally invasive versus open transforaminal lumbar interbody fusion. J Spinal Disord Tech 2014; 27:202-206.

12. Evaniew N, Khan M, Drew B, Kwok D, Bhandari $M$, Ghert M. Minimally invasive versus open surgery for cervical and 
lumbar discectomy: A systematic review and meta-analysis. CMA] Open 2014; 2:E295-E305.

13. Fourney DR, Dettori JR, Norvell DC, Dekutoski MB. Does minimal access tubular assisted spine surgery increase or decrease complications in spinal decompression or fusion? Spine (Phila Pa 1976) 2010; 35:S57-S65.

14. Dasenbrock $\mathrm{HH}$, Juraschek SP, Schultz LR, Witham TF, Sciubba DM, Wolinsky JP, Gokaslan, ZLL.Bydon, A.The efficacy of minimally invasive discectomy compared with open discectomy: A metaanalysis of prospective randomized controlled trials. J Neurosurg Spine 2012; 16:452-462.

15. Smith N, Masters J, Jensen C, Khan A, Sprowson A. Systematic review of microendoscopic discectomy for lumbar disc herniation. Eur Spine J 2013; 22:2458-2465.

16. Chang X, Chen B, Li HY, Han XB, Zhou $\mathrm{Y}, \mathrm{Li}$ CQ. The safety and efficacy of minimally invasive discectomy: A meta-analysis of prospective randomised controlled trials. Int Orthop 2014; 38:1225-1234.

17. Kamper SJ, Ostelo RW, Rubinstein SM, Nellensteijn JM, Peul WC, Arts MP, van Tulder MW. Minimally invasive surgery for lumbar disc herniation: A systematic review and meta-analysis. Eur Spine J 2014; 23:1021-1043.

18. Rasouli MR, Rahimi-Movaghar V, Shokraneh F, Moradi-Lakeh M, Chou R. Minimally invasive discectomy versus microdiscectomy/open discectomy for symptomatic lumbar disc herniation. Cochrane Database Syst Rev 2014; 9:Cdo10328.

19. Adogwa O, Carr K, Thompson P, Hoang K, Darlington T, Perez E, Fatemi $P$, Gottfried O, Cheng J, Isaacs RE. A prospective, multi-institutional comparative effectiveness study of lumbar spine surgery in morbidly obese patients: Does minimally invasive transforaminal lumbar interbody fusion result in superior outcomes? World Neurosurg 2015; 83:860-866.

20. Ruetten S, Komp M, Merk H, Godolias $\mathrm{G}$. A new full-endoscopic technique for cervical posterior foraminotomy in the treatment of lateral disc herniations using 6.9-mm endoscopes: Prospective 2-year results of 87 patients. Minim Invasive Neurosurg 2007; 50:219-226.

21. Birkenmaier C, Komp M, Leu HF, Wegener B, Ruetten $\mathrm{S}$. The current state of endoscopic disc surgery: Review of controlled studies comparing full-endoscopic procedures for disc herniations to standard procedures. Pain Physician 2013; 16:335-344.

22. Hermantin FU, Peters T, Quartararo L, Kambin P. A prospective, randomized study comparing the results of open discectomy with those of video-assisted arthroscopic microdiscectomy. ] Bone Joint Surg Am 1999; 81:958-965.

23. Arts MP, Brand R, van den Akker ME, Koes BW, Bartels RH, Peul WC. Tubular diskectomy vs conventional microdiskectomy for sciatica: A randomized controlled trial. JAMA 2009; 302:149-158.

24. Arts $M$, Brand $R$, van der Kallen $B$, Lycklama a Nijeholt G, Peul W. Does minimally invasive lumbar disc surgery result in less muscle injury than conventional surgery? A randomized controlled trial. Eur Spine J 2011; 20:51-57.

25. Lee JC, Jang HD, Shin BJ. Learning curve and clinical outcomes of minimally invasive transforaminal lumbar interbody fusion: Our experience in 86 consecutive cases. Spine (Phila Pa 1976) 2012; 37:1548-1557

26. Lee $\mathrm{KH}$, Yeo W, Soeharno H, YueWM. Learning curve of a complex surgical technique: Minimally invasive transforaminal lumbar interbody fusion (MIS TLIF). J Spinal Disord Tech 2014; 27:E234-E240.

27. Sclafani JA, Kim CW. Complications associated with the initial learning curve of minimally invasive spine surgery: A systematic review. Clin Orthop Relat Res 2014; 472:1711-1717.

28. Allen RT, Garfin SR. The economics of minimally invasive spine surgery: the value perspective. Spine (Phila Pa 1976) 2010; 35:S375-S382.

29. Higgins JPT, Green S (2011) Cochrane handbook for systematic reviews of interventions version 5.1.0 (updated March 2011). The Cochrane Collaboration. Available from www.

cochrane-handbook.org.

30. A. Liberati, D. G. Altman, J. Tetzlaff, C. Mulrow, P. C. Gotzsche, J. P. Ioannidis, M. Clarke, P. J. Devereaux, J. Kleijnen, D. Moher, The PRISMA statement for reporting systematic reviews and meta-analyses of studies that evaluate health care interventions: explanation and elaboration. PLoS Med 2009; 6: e1000100.

31. Liberati A, Altman DG, Tetzlaff J, Mulrow $C$, Gotzsche PC, loannidis JP, et al. The PRISMA statement for reporting systematic reviews and meta-analyses of studies that evaluate health care interventions: explanation and elaboration. Journal of clinical epidemiology 2009;62:e1-34.

32. Higgins JP, Thompson SG, Deeks JJ, Altman DG. Measuring inconsistency in meta-analyses. BMJ 2003; 327:557-56o.

33. Stang A. Critical evaluation of the Newcastle-Ottawa scale for the assessment of the quality of nonrandomized studies in meta-analyses. Eur J Epidemiol 2010; 25:603-605.

34. Ruetten S, Komp M, Merk H, Godolias G. Recurrent lumbar disc herniation after conventional discectomy: A prospective, randomized study comparing full-endoscopic interlaminar and transforaminal versus microsurgical revision. J Spinal Disord Tech 2009; 22:122-129.

35. Ruetten S, Komp M, Merk H, Godolias G. Full-endoscopic anterior decompression versus conventional anterior decompression and fusion in cervical disc herniations. Int Orthop 2009; 33:1677-1682.

36. Ruetten S, Komp M, Merk H, Godolias G. Full-endoscopic interlaminar and transforaminal lumbar discectomy versus conventional microsurgical technique: A prospective, randomized, controlled study. Spine (Phila Pa 1976) 2008; 33:931-939.

37. Ruetten S, Komp M, Merk H, Godolias G. Full-endoscopic cervical posterior foraminotomy for the operation of lateral disc herniations using $5.9-\mathrm{mm}$ endoscopes: A prospective, randomized, controlled study. Spine (Phila Pa 1976) 2008; 33:940-948.

38. Guyatt $\mathrm{GH}$, Oxman $A D$, Vist GE, Kunz R, Falck-Ytter $Y$, Alonso-Coello P, Schunemann HJ. GRADE: An emerging consensus on rating quality of evidence and strength of recommendations. BM] 2008; 336:924-946.

39. Guyatt G, Oxman AD, Akl EA, Kunz R, Vist G, Brozek J, Norris S, Falck-Ytter Y, Glasziou P, DeBeer H, Jaeschke R, Rind D, Meerpohl J, Dahm P, Schunemann HJ. GRADE guidelines: 1 . IntroductionGRADE evidence profiles and summary of findings tables. J Clin Epidemiol 2011; 64:383-394.

40. Meerpohl JJ, Langer G, Perleth M, Gartlehner G, Kaminski-Hartenthaler $A$, Schunemann $H$. [GRADE guidelines: 3. Rating the quality of evidence (confidence in the estimates of effect)]. Z Evid Fortbild Qual Gesundhwes 2012; 106:449-456. 
41. Lee DY, Shim CS, Ahn Y, Choi YG, Kim HJ, Lee SH. Comparison of percutaneous endoscopic lumbar discectomy and open lumbar microdiscectomy for recurrent disc herniation. J Korean Neurosurg Soc 2009; 46:515-521.

42. Wang B, Lu GH, Li J, Kang YJ, Deng YW, Liu WD, Hu JR, Li L, Chen F, Chen WH, Kuang L, Wang XB. [Contrast study of full-endoscopic interlaminar approach for the surgical treatment of lumbar disc herniation]. Zhonghua Wai Ke Za Zhi 2011; 49:74-78.

43. Manchikanti L, Falco FJ, Benyamin RM, Kaye AD, Boswell MV, Hirsch JA. A modified approach to grading of evidence. Pain Physician 2014; 17:E319-E325.

44. Atkins D, Briss PA, Eccles M, Flottorp S, Guyatt GH, Harbour RT, Hill S, Jaeschke R, Liberati A, Magrini N, Mason J, O'Connell D, Oxman AD, Phillips B, Schunemann $H$, Edejer TT, Vist GE, Williams JW Jr. Systems for grading the quality of evidence and the strength of recommendations II: Pilot study of a new system. BMC Health Serv Res 2005; 5:25.

45. Ruetten S, Komp M, Godolias G. An extreme lateral access for the surgery of lumbar disc herniations inside the spinal canal using the full-endoscopic uniportal transforaminal approachtechnique and prospective results of 463 patients. Spine (Phila Pa 1976) 2005; 30:2570-2578.
46. Ruetten S, Komp M, Godolias G. A New full-endoscopic technique for the interlaminar operation of lumbar disc herniations using 6-mm endoscopes: Prospective 2-year results of $331 \mathrm{pa}$ tients. Minim Invasive Neurosurg 2006; 49:80-87.

47. Parker SL, Adogwa O, Witham TF, Aaronson OS, Cheng J, McGirt MJ. Post-operative infection after minimally invasive versus open transforaminal lumbar interbody fusion (TLIF): Literature review and cost analysis. Minim Invasive Neurosurg 2011; 54:33-37.

48. Smith ZA, Fessler RG. Paradigm changes in spine surgery: Evolution of minimally invasive techniques. Nat $\mathrm{Rev} \mathrm{Neu-}$ rol 2012; 8:443-450.

49. Haque RM, Hashmi SZ, Ahmed Y, Uddin O, Ogden AT, Fessler R. Primary dural repair in minimally invasive spine surgery. Case Rep Med 2013; 2013:876351.

50. Ross DA. Complications of minimally invasive, tubular access surgery for cervical, thoracic, and lumbar surgery. Minim Invasive Surg 2014; 2014:451637.

51. Wong AP, Shih P, Smith TR, Slimack NP, Dahdaleh NS, Aoun SG, El Ahmadieh TY, Smith ZA, Scheer JK, Koski TR, Liu JC, Fessler RG. Comparison of symptomatic cerebral spinal fluid leak between patients undergoing minimally invasive versus open lumbar foraminotomy, discectomy, or laminectomy. World
Neurosurg 2014; 81:634-640.

52. Lau D, Khan A, Terman SW, Yee T, La Marca F, Park P. Comparison of perioperative outcomes following open versus minimally invasive transforaminal lumbar interbody fusion in obese patients. Neurosurg Focus 2013; 35:E10.

53. Parker SL, Lerner J, McGirt MJ. Effect of minimally invasive technique on return to work and narcotic use following transforaminal lumbar inter-body fusion: A review. Prof Case Manag 2012; 17:229-235.

54. Kepler CK, Yu AL, Gruskay JA, Delasotta LA, Radcliff KE, Rihn JA, Hilibrand AS, Anderson DG, Vaccaro AR. Comparison of open and minimally invasive techniques for posterior lumbar instrumentation and fusion after open anterior lumbar interbody fusion. Spine J 2013; 13:489-497.

55. Terman SW, Yee TJ, Lau D, Khan AA, La Marca F, Park P. Minimally invasive versus open transforaminal lumbar interbody fusion: Comparison of clinical outcomes among obese patients. J Neurosurg Spine 2014; 20:644-652.

56. Eichen PM, Achilles N, Konig V, Mosges R, Hellmich M, Himpe B, Kirchner R. Nucleoplasty, a minimally invasive procedure for disc decompression: A systematic review and meta-analysis of published clinical studies. Pain Physician 2014; 17:E149-E173. 